Saudi Journal of Medical and Pharmaceutical Sciences

Abbreviated Key Title: Saudi J Med Pharm Sci

ISSN 2413-4929 (Print) |ISSN 2413-4910 (Online)

Scholars Middle East Publishers, Dubai, United Arab Emirates

Journal homepage: https://saudijournals.com

Original Research Article

\title{
"Clinical Spectrum of Enteric Fever in Children: A Study in a Tertiary Care Hospital, Bangladesh"
}

\author{
Farhana Jaya Chowdhury ${ }^{1 *}$, Khairul Bashar AHM ${ }^{2}$, Shahabuddin ${ }^{3}$, Md. Nurul Amin ${ }^{4}$, Murshida Afruz ${ }^{5}$ \\ ${ }^{1}$ Assistant Professor (Paediatric), Sylhet Womens Medical College Hospital, Sylhet, Bangladesh \\ ${ }^{2}$ Assistant Professor (Paediatric), Sylhet M.A.G Osmani Medical College Hospital, Sylhet, Bangladesh \\ ${ }^{3}$ Associate Professor \& In Charge Of NICU, Sylhet Womens Medical College Hospital, Sylhet, Bangladesh \\ ${ }^{4}$ Associate Professor \& Head of Anaesthesiology, Sylhet Womens Medical College Hospital, Sylhet, Bangladesh \\ ${ }^{5}$ Assistant Professor (Gynae), Sylhet Womens Medical College Hospital, Sylhet, Bangladesh
}

\begin{abstract}
DOI: $10.36348 /$ sjmps.2021.v07i02.008 $\quad$ | Received: 22.01.2021 | Accepted: 08.02.2021 | Published: 19.02.2021
*Corresponding author: Farhana Jaya Chowdhury
\end{abstract}

\section{Abstract}

Background: Enteric fever is a common public health problem in Bangladesh and it involves multiple symptoms. Enteric fever presents with variable clinical scenario. Objective: The aim of study was to evaluate the clinical spectrum of enteric fever in children. Methods: A prospective study was done in the department of Paediatrics, Sylhet Womens Medical College Hospital and Sylhet M.A.G Osmani Medical College Hospital, Sylhet, Bangladesh during the period from January 2019 to December 2019 who was clinically suspected to have enteric fever and had either a positive blood culture for Salmonella or a positive Widal test. Results: This study included 133 patients out of which 71 were males and 62 were females. The majority of patients were under 5 years. The age distribution of study population in depicted and the sex distribution. The most common presenting symptoms in our study was fever (97.0\%), abdominal pain $(39.8 \%)$, vomiting $(39.1 \%)$, diarrohea $(36.1 \%)$, and the common symptom was constipation (18.8\%) as depicted in table III. The most common physical findings was coated tongue (74.4\%), followed by toxic look (63.9\%), pallor (51.9\%), abdominal distension (15.0\%), abdominal tenderness (13.5\%), Rose spots (14.3\%), hepatomegaly (16.5\%), splenomeagly $(3.8 \%)$, and jaundice $(4.5 \%)$ as depicted in Figure-1. Complications were present in nine patients $(6.77 \%)$, Pneumonia was present in five patients $(3.76 \%)$, hepatitis in three patents $(2.25 \%)$ and encephalopathy in the patient $(0.75 \%)$. Conclusions: Enteric fever is a common public health problem with fever as most common presenting symptom. Culture yield can be increased in enteric fever by drawing blood culture prior to administration of antibiotics. Ceftriaxone is highly efficacious as monotherapy in enteric fever.

Keywords: Enteric fever. Clinical spectrum, Paediatric infection.

Copyright (C) 2021 The Author(s): This is an open-access article distributed under the terms of the Creative Commons Attribution 4.0 International License (CC BY-NC 4.0) which permits unrestricted use, distribution, and reproduction in any medium for non-commercial use provided the original author and source are credited.

\section{INTRODUCTION}

Enteric fever causes prolonged illness characterized by bacteraemia. Sub-species enterica Serovar Typhi and Salmonella Paratyphi A, B and C [1]. It continues to be a global public health problem with over 21 million cases and at least 216,510 deaths occurring annually $[2,3]$. Several studies in areas of endemicity and outbreaks have shown that about onequarter to one third of pediatric enteric fever cases are under five years of age, and that between $6 \%$ and $12 \%$ are under two years of age [4-7]. Enteric fever causes prolonged illness characterized by loacteriac. The clinical presentation varies from mild illness with low grade fever, malaise and slight dry cough to a serve clinical presentation with abdominal pain and multiple complications. Enteric fever usually presents with fever, anorexics, abdominal pain, diarrohea, constipation, weakness [8]. The presentation of Enteric fever may be more dramatic in children younger than 5 years type with comparatively higher rates of complications and hospitalization. Diarrhea, toxicity, and complications such as disseminated intravascular coagulopathy are also more common in infancy. If there are no complications, the symptoms and physical finding gradually improve within 2-4 weeks [9]. Our aim was to evaluate the clinical spectrum of Enteric fever in children admitted in the hospital.

\section{MeTHODS}

A prospective study was done in the department of Paediatrics, Sylhet Womens Medical College Hospital and Sylhet M.A.G Osmani Medical College Hospital, Sylhet, Bangladesh during the period from January 2019 to December 2019. All the patients 
Farhana Jaya Chowdhury et al., Saudi J Med Pharm Sci, Feb, 2021; 7(2): 126-129

in the age group of 1 to 15 years with clinically suspected enteric fever and either Widal or Blood culture was positive were included in this study. All patients were subjected to detailed history and examination. Baseline investigations were done in all patients. In addition to baseline investigation blood culture and Widal test was done in all patients. Blood culture was done after taking proper aseptic precautions. Blood culture was done by BACT/ALERT Automated system and positive cultures were characterized using standard bacteriological procedures. Widel was done by tbe agglutination test. A titre of $\geq$ $1: 160$ to either 0 or $\mathrm{H}$ antigen in a single serum specimen was taken as indicator of typhoid fever. Data were entered and analyzed using SPSS version 23. Data has been summarized using percentage and table.

\section{RESULTS}

This study included 133 patients out of which 71 were males and 62 were females. The majority of patients $81(60.2 \%)$ were under 5 years (Table-1) and Male were dominated in sex distribution 71(53.4\%) (Table-2). The most common presenting symptoms in our study was fever $(97.0 \%)$, abdominal pain $(39.8 \%)$, vomiting $(39.1 \%)$, diarrohea $(36.1 \%)$, and the common symptom was constipation (18.8\%) as depicted (Table3 ). The most common physical findings was coated tongue $(74.4 \%)$, followed by toxic look $(63.9 \%)$, pallor (51.9\%), abdominal distension (15.0\%), abdominal tenderness $(13.5 \%)$, Rose spots $(14.3 \%)$, hepatomegaly (16.5\%), splenomeagly (3.8\%), and jaundice (4.5\%) as depicted (Figure-1). Complications were present in nine patients $(6.77 \%)$, Pneumonia was present in five patients $(3.76 \%)$, hepatitis in three (3) patients $(2.25 \%)$ and encephalopathy in one (1) patient $(0.75 \%)$ as shown (Table-4).

Table-1: Age distribution of the Enteric fever in children $(\mathrm{N}=133)$

\begin{tabular}{|l|l|l|}
\hline Age Group & No. Patients $\mathbf{n = 1 3 3}$ & \% \\
\hline$<60$ months & 81 & 60.2 \\
\hline$>60$ months & 53 & 39.8 \\
\hline
\end{tabular}

Table-2: Sex distribution of the Enteric fever in children $(\mathrm{N}=133)$

\begin{tabular}{|l|l|l|}
\hline Variables & No. Patients n=133 & \% \\
\hline Male & 71 & 53.40 \\
\hline Female & 62 & 46.60 \\
\hline
\end{tabular}

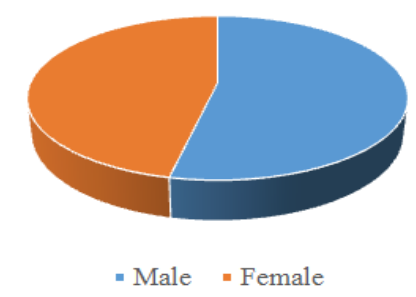

Fig-1: Sex distribution of the Enteric fever in children.
Table-3: Symptoms of the Enteric fever in children (N=133)

\begin{tabular}{|l|l|l|}
\hline Preventive Symptom & No. Patients n=133 & \% \\
\hline Fever & 129 & 97.0 \\
\hline Abdominal pain & 53 & 39.8 \\
\hline Vomiting & 52 & 39.1 \\
\hline Diarohaea & 48 & 36.1 \\
\hline Constipation & 25 & 18.8 \\
\hline
\end{tabular}

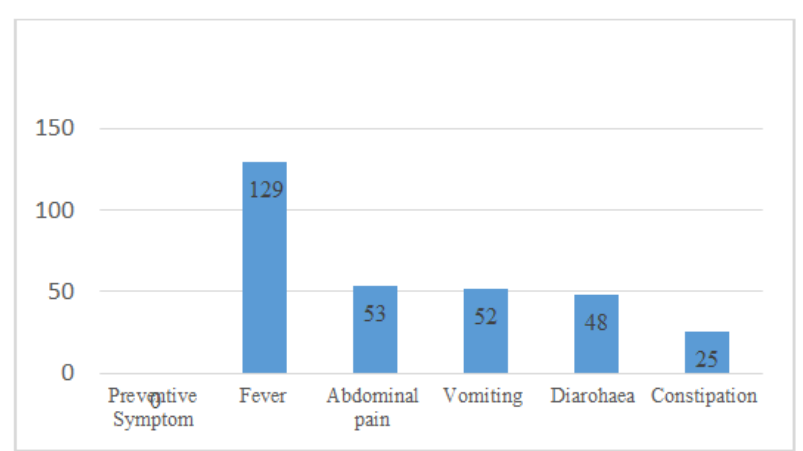

Fig-2: Symptoms of the Enteric fever in children

Table-4: Complications of the Enteric fever in children $(\mathbf{n}=9)$

\begin{tabular}{|l|l|l|}
\hline Complications & No. Patients n=9 & \% \\
\hline Pneumonia & 5 & 3.76 \\
\hline Hepatitis & 3 & 2.25 \\
\hline Encephalopathy & 1 & 0.75 \\
\hline
\end{tabular}

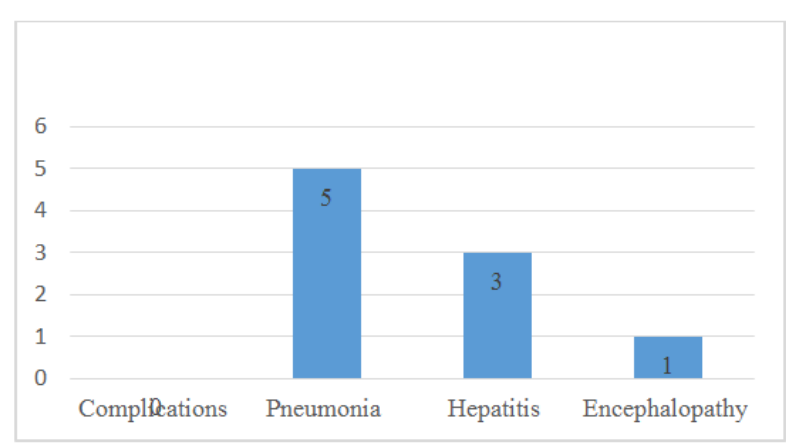

Fig-3: Complications of the Enteric fever in children.

\section{DISCUSSION}

Enteric fever is still a significant public health problem in developing countries. It is a dread disease because of its long course and associated complications if not detected and treated early. Typhoid fever is endemic in Bangladesh, where there is a high incidence in children [10]. In this study we found $60 \%$ of children were less than five years, which is also in agreement with an earlier of $43.9 \%$ prevalence rate in Cebn city, Phillipine [11]. The scene is that children are the most vulnerable group in environments where inadequate pure water supply and poor environmental hygine are problems. Fever who seen in almost all patients (97\%). Similar results were seen in studies doneby Kundu R et al., Ganesh R et al., Walia $\mathrm{M}$ et al., and S Jog et al., [12-15]. Vomiting was seen in $53(39.1 \%)$ patients 
which is similar to study done by S Jog et al., [15]. Diarrhoea was seen in 48 (36.1\%) which is comparable to study done by Ganesh et al., and S Jog et al., [13-15]. Abdominal pain was seen in $53(39.8 \%)$ patients and it different from study done by Abdus S. Bhat et al., [16] where they showed only $18.4 \%$ constipation was seen in $25(18.8 \%)$ which is comparable to studies done by Comeau et al., and Taneja PN et al., [17, 18]. In this study coated tongue and toxic look were the most clinical findings. Coated tongue was seen in 99 (74.4\%) patients similar to studies done by R Modi and Iqbal et al., [19, 20]. Toxic look was seen in $85(63.9 \%)$ patients similar to study done by Sood and Taneja [21]. Pallor was seen in 69 patients $(51.9 \%)$ patients. Our study defer with Abdus S. Bhat et al., [16] study where they showed only $32.8 \%$. Hepatomeagly was seen in 22 (16.5\%) patients who are differing to studies done by $\mathrm{R}$ Modi Chowta MN et al., and Jeeyani $\mathrm{H}$ et al., [22, 19, 23]. Splenomeagly was seen in $5(3.8 \%)$ patients which is also dissimilar to studies done by S Jog et al., and Jeeyani $\mathrm{H}$ et al., $[15,23]$ Complications were seen in 9 $(6.77 \%)$ patients which is similar to study done by Jeeyani $\mathrm{H}$ et al., [23]. Pneumonia was seen in 5 (3.76\%) cases and hepatitis $3(2.25 \%)$ cases. Encephalopathy was seen in $1(0.75 \%)$ cases similar to study done by Md. Salim et al., [24]. The mean time to defervescence was 5.5 days which is similar to studies done by S Jog et al., and Parry et al., [15, 25].

\section{CONCLUSION}

Enteric is a very common public health problem with fever as major presenting symptom. Blood culture yield can be increased by drawing blood sample prior to administration of antibiotics. Majority of enteric fever have uncomplicated course. Ceftriaxone is highly efficacious against enteric fever till date.

\section{REFERENCES}

1. Behrman, R.E., Kliegman, R.M., Jenson, H.B. (2004). Nelson Textbook of Pediatrics. 18th ed. Philadelphia: Elsevier, 1386-1391.

2. Crump, J. A., Luby, S. P., \& Mintz, E. D. (2004). The global burden of typhoid fever. Bulletin of the World Health Organization, 82, 346-353.

3. Jhon, A., Crump, E.D, Mintz. (2010). Global trends in typhoid and paratyphoid fever. Clinical infection, 50:241-46.

4. Crump, J. A., Youssef, F. G., Luby, S. P., Wasfy, M. O., Rangel, J. M., Taalat, M., ... \& Mahoney, F. J. (2003). Estimating the incidence of typhoid fever and other febrile illnesses in developing countries. Emerging infectious diseases, 9(5), 539.

5. Sinha, A., Sazawal, S., Kumar, R., Sood, S., Reddaiah, V. P., Singh, B., ... \& Bhan, M. K. (1999). Typhoid fever in children aged less than 5 years. The Lancet, 354(9180), 734-737.
6. Brooks, W. A., Hossain, A., Goswami, D., Sharmeen, A. T., Nahar, K., Alam, K., ... \& Breiman, R. F. (2005). Bacteremic typhoid fever in children in an urban slum, Bangladesh. Emerging infectious diseases, 11(2), 326.

7. Naheed, A., Ram, P. K., Brooks, W. A., Hossain, M. A., Parsons, M. B., Talukder, K. A., ... \& Breiman, R. F. (2010). Burden of typhoid and paratyphoid fever in a densely populated urban community, Dhaka, Bangladesh. International Journal of Infectious Diseases, 14, e93-e99.

8. David, A.P., Samual, I.M. (2015). Salmonellosis. In Harrison's principles of internal medicine. $19^{\text {th }}$ ed. Mcgraw; 2015:1049-57.

9. Bhutta, Z. A. (2016). Enteric Fever (Typhoid Fever). In: Behrman RE, Kliegman RM, Jenson HB, Stanton FB (Eds). Nelson Textbook of Pediatrics. 20th ed. Philadelphia: WB Saunders, 1388-1391.

10. Saha, S. K., BAQUI, A. H., Hanif, M., Darmstadt, G. L., Ruhulamin, M., Nagatake, T., ... \& Black, R. E. (2001). Typhoid fever in Bangladesh: implications for vaccination policy. The Pediatric infectious disease journal, 20(5), 521-524.

11. Virginia, V. (1995). Pate-Mesala and Manual Emerson S. Donaldo. Antimicrobial susceptibility of S. typhi isolated from government and private hospital in Cuba cita. Philippine journal of microbiology and infection disease, 26(1):5-8.

12. Kundu, R., Ganguly, N., Ghosh, T. K., Choudhury, P., \& Shah, R. C. (2005). Diagnosis and management of malaria in children: recommendations and IAP plan of action. Indian pediatrics, 42(11), 1101-1114.

13. Ganesh, R., Janakiraman, L., Vasanthi, T., \& Sathiyasekeran, M. (2010). Profile of typhoid fever in children from a tertiary care hospital in Chennai-South India. The Indian Journal of Pediatrics, 77(10), 1089-1092.

14. Walia, M., Gaind, R., Paul, P., Mehta, R., Aggarwal, P., \& Kalaivani, M. (2006). Agerelated clinical and microbiological characteristics of enteric fever in India. Transactions of the Royal Society of Tropical Medicine and Hygiene, 100(10), 942948.

15. Jog, S., Soman, R., Singhal, T., Rodrigues, C., Mehta, A., \& Dastur, F. D. (2008). Enteric fever in Mumbai-clinical profile, sensitivity patterns and response to antimicrobials. JAPI, 56, 237-40.

16. Wani, J. N., Bhat, A. S., Yusuf, S., \& Qureshi, U. A. (2020). Clinical spectrum of enteric fever in children admitted to a tertiary care hospital.

17. Comeau, J. L., Tran, T. H., Moore, D. L., Phi, C. M., \& Quach, C. (2013). Salmonella enterica serotype Typhi infections in a Canadian pediatric 
hospital: a retrospective case series. CMAJ open, 1(1), E56.

18. Taneja, P.N., Ghai, K. (1997). Clinical study of enteric fever. Indian Podiatry, 34(6):237-9.

19. Modi, R. (2016). Clinical profile and treatment outcome of typhoid fever in children at a teaching hospital, Ahmedabad, Gujarat, India. Int J Med Sci Public Health, 5, 212.

20. Iqbal, S. M. J., Serfraz, M., \& Khan, M. M. N. (2004). Clinical spectrum of typhoid fever in children. Annals of King Edward Medical University, 10(4).

21. Sood, S. C., \& Taneja, P. N. (1961). Typhoid Fever. Clinical Picture and Diagnosis. Indian Journal of Child Health, 10(2), 69-76.
22. Chowta, M. N., \& Chowta, N. K. (2005). Study of clinical profile and antibiotic response in typhoid fever. Indian Journal of Medical Microbiology, 23(2), 125.

23. Jeeyani, H. N., Prajapati, B. S., \& Bloch, A. (2015). Enteric Fever in Children-Clinical profile, sensitivity patterns and response to antimicrobials. GCSMC J Med Sci, 4(1), 40-3.

24. Salim, M., Hita, S.A., Shahid, A.T., Khahil, M.I., Hossain, M.N. (2019). Scholars J applied medical sciences, 7(12):393-9.

25. Parry, C.M., Hien, T.T., Dougan, G., White, N.J., Farrar, J.J. (2002). Typhoid fever. N Engl J Med, 347(22):1770-1782. 